DOI https://doi.org/10.36059/978-966-397-159-9/36-51

\title{
COORDINATION OF ACTIVITY OF BODIES AND SERVICES PERFORMING DIFFERENT TYPES OF CONTROL AT THE STATE BORDER
}

\section{Valerii Kukhar}

\section{INTRODUCTION}

Among the main functions of the SBGSU defined in article 2 of the Law of Ukraine «On the State Border Guard Service of Ukraine» is the coordination of activity of military formations and law enforcement agencies related to the protection of the state border and the activity of the state bodies, that perform various types of control when crossing the state border ${ }^{1}$.

The activity of the state bodies and various services that carry out various types of control when crossing the state border by persons, vehicles and transporting goods across it or participate in ensuring the regime at checkpoints are coordinated by the state border protection bodies also in accordance with part 1 of the article 25 of the Law of Ukraine «On border control» ${ }^{2}$. At the same time, inadequate coordination of the activity of the subjects of integrated border management is defined as one of the problems of integrated border management in the Strategy of integrated border management for the period up to $2025^{3}$.

Among the border management issues identified by the Strategy are:

the inadequacy of the infrastructure of checkpoints and access roads to the growing needs for processing capacity;

periodic complications in the operation of existing border crossing points due to seasonal and other changes in cross-border traffic flows;

inadequate condition of service areas and lack of comfortable conditions for travelers;

obsolescence of technical means of control;

${ }^{1}$ Pro Derzhavnu prykordonnu sluzhbu Ukrayiny: Zakon Ukrayiny vid 3 kvitnya 2003 roku [On the State border service of Ukraine: Law of Ukraine] No. 661-IV of 3 April 2003. URL: http://zakon3.rada.gov.ua/laws/show/661-15/print1533466816482616.

${ }^{2}$ Pro prykordonnyy kontrol': Zakon Ukrayiny Zakon Ukrayiny vid 5.11.2009 r. [On border control: the Law of Ukraine] of 5.11.2009 No. 1710-VI URL: http://zakon2.rada.gov.ua/ laws/show/1710-17/print1520522429510622

3 Stratehiya intehrovanoho upravlinnya kordonamy na period do 2025 r. Skhvalena rozporyadzhennyam KMU vid 24 lypnya 2019 r. № 687-r. [Integrated border management strategy]. Approved by the order of the CMU dated July 24, 2019 No. 687-R. URL: https://www.kmu.gov.ua/storage/app/uploads/public/5d6/904/d22/5d6904d225eb5667852251.doc 
low motivation and insufficient level of training of the personnel of subjects of integrated border management, their unwillingness to counteract corruption challenges. ${ }^{4}$

It is safe to say that some of these problems are directly or indirectly related to an inadequate level of coordination.

Moreover, the absence of the concept of «the state border at the checkpoint» does not allow purposefully and logically build technological lines of border, customs and other types of control, that are carried out at the checkpoint, to determine the responsibility of departments and officials for performing the tasks, functions and duties necessary for the implementation of the border crossing $^{5}$.

In turn, according to part 1 of the article 2 of the law of Ukraine «On border control», border control is a state control of the State border guard service of Ukraine that includes a set of actions and a system of measures aimed at establishing legal grounds for crossing the state border by persons, vehicles and moving goods through it, to counteract illegal movement of persons across the state border, illegal migration, human trafficking, and illegal movement of weapons, drugs, psychotropic substances and precursors, ammunition, explosives, materials and articles banned for transfer across the state border ${ }^{6}$.

At the same time, according to part 2 of article 2 of the Law of Ukraine «On border control», the purpose of border control is actually defined as counteraction to cross-border crime, it follows that the inconsistency of the activities of various control services at checkpoints across the state border negatively affects such counteraction, which determines the relevance of this work.

1. General characteristics of coordination of joint border activity

Ukraine has a developed network of border crossing points. The passage of persons and vehicles across the state border is carried out at 229 checkpoints (including control points), of which: 166-international, 28-interstate and 35local. By type of communication - 100 automobile, 57 rail, 29 sea, 28 air, 10 river, 2 ferry and 3 pedestrian checkpoints (including control points) ${ }^{7}$.

${ }^{4}$ Ibid

${ }^{5}$ Mostova K. (2017) Orhanizatsiyno-pravovi zasady prykordonnoho kontrolyu v punktakh peretynu derzhavnoho kordonu Ukrayiny [Organizational and legal basis of border control at the state border crossing points of Ukraine]. University scientific notes. No. 62, Pp. 241-254. P. 245.

${ }^{6}$ Pro prykordonnyy kontrol': Zakon Ukrayiny Zakon Ukrayiny vid 5.11.2009 r. [On border control: the Law of Ukraine] of 5.11.2009 No. 1710-VI URL: http://zakon2.rada.gov.ua/ laws/show/1710-17/print1520522429510622

7 Stratehiya intehrovanoho upravlinnya kordonamy na period do 2025 r. Skhvalena rozporyadzhennyam KMU vid 24 lypnya 2019 r. № 687-r. [Integrated border management strategy]. Approved by the order of the CMU dated July 24, 2019 No. 687-R. URL: https://www.kmu.gov.ua/storage/app/uploads/public/5d6/904/d22/5d6904d225eb5667852251.doc 
In fact, this infrastructure works in the interests of countering cross-border offenses - both administrative and criminal.

The analysis of historical experience shows that with the development of the state there was a clear tendency to increase the share of border control tasks in the total volume of tasks of the Border Guard Agency. If before 1960 their share was $10 \%$, in 1960-1982-30\%, in 1982-1991 their share was $45 \%$, then after 2003 (adoption of the law «On the State border guard service of Ukraine») already $70 \%$.

At first glance, the purpose of border control in accordance with the cited norm of the Law «On border control» is to counteract the acts provided for in articles 332, 149, 201, 305 of the Criminal Code of Ukraine. However, based on a comprehensive analysis of other norms of this and other Laws, it seems obvious that this list is not complete (in particular, we are talking, for example, about articles 332-1, 358, 204 and a number of other norms of the Criminal Code of Ukraine).

Ukraine borders with 7 States, 4 of them are EU members. The signing of the Association Agreement between Ukraine, the European Union, the European atomic energy community and their member States determined the strengthening of cooperation between Ukraine and the EU in the field of justice, freedom and security in order to ensure the rule of law and respect for human rights and fundamental freedoms. In this regard, it is necessary to take into account the peculiarities of the functioning of the system of combating criminal threats on the external borders of the European Union. It should be noted that the interests of Ukraine and neighboring States in this area coincide on such issues:

ensuring unhindered legal border crossing by persons and vehicles at checkpoints across the state border (hereinafter-BCP across the state border) in combination with a high level of control procedures;

proper management of migration flows,

effective counteraction to cross-border crime, especially its organized forms ${ }^{9}$

Therefore, often neighboring states seek to unify the technology of control procedures or organize joint border control. For example, in April 2018, Ukraine completed the procedure of ratification of the Agreement between the Cabinet of Ministers of Ukraine and the Government of the Republic of Moldova «On joint control of persons, vehicles, goods and objects at joint checkpoints across the Ukrainian-Moldovan state border». The analysis of the tasks of border control

${ }^{8}$ Stavytskyi, O. (2013) Teoriya i praktyka orhanizatsiyi ta zdiysnennya prykordonnoho kontrolyu v konteksti zabezpechennya natsional'noyi bezpeky Ukrayiny v prykordonniy sferi : monohrafiya.[Theory and practice of organization and implementation of border control in the context of national security in the border guard area: monograph]. Khmelnytskyi: NADPSU Publishing house. P. 90.

${ }^{9}$ Filippov S. (2019) Protydiia transkordonnii zlochynnosti: hlobalnyi kontekst i realii Ukrainy: monohrafiia [Countering cross-border crime: the global context and realities of Ukraine] Odesa: Feniks. 452 p. 
carried out in different States allows to draw a conclusion about a significant degree of similarity of these tasks in the context of their anti-criminal orientation. To illustrate this thesis, we will analyze the cross-border threats, which are counteracted at the line of border control.

The separation of cross-border criminal threats from all others is of a practical nature, primarily related to the peculiarities of countering them. In fact, the state border is a global filter, using which the states can take the necessary measures to ensure the most effective implementation of the functions of criminal justice. Border control in Ukraine contains:

1) verification of documents;

2) inspection of persons, vehicles, cargo;

3) execution of orders of law enforcement agencies of Ukraine;

4) verification of compliance by foreigners, stateless persons with the conditions of crossing the state border when entering, exiting and transiting through the territory of Ukraine;

5) registration of foreigners, stateless persons and their passport documents in BCPs through the state border;

6) inspection of vehicles in order to identify stolen vehicles.

Similar tasks are carried out in the course of border control in most European States. In this regard, let's detail performed by units of border control orders issued by authorized state bodies, that is, written instructions of the authorized state bodies about conducting in reference to certain individuals (in certain cases and in a certain way) of certain procedural, operational or special events.

Etymologically, the term «coordination» means coordination, bringing into line, establishing relationships, contact in the activity of people, between actions, concepts ${ }^{10}$. Despite this, it should be noted that the essence of coordination in the field of state border protection is to coordinate the goals, plans, content and forms of activity, resource potential of all state bodies and other units that ensure the state border regime. The main goal of the coordination is to achieve maximum efficiency in using the capabilities of public authorities in protecting the interests of the state in the border areas, maintaining reliable security of its borders. It is implemented by joint efforts of all subjects of coordination, taking into account the interests and specifics of their activities on the basis of jointly developed programs.

Various aspects of this problem are covered in the works of K. Mostova, O. Stavitsky, S. Filippov et al. However, the analysis of criminological and organizational-legal features of coordination by the state border protection bodies of the activity of control bodies and services exercising various types of control or taking part in ensuring the regime at checkpoints across the state border remained without attention. This is connected with the solution of the

${ }^{10}$ Suchasnyy tlumachnyy slovnyk ukrayins'koyi movy [Modern explanatory dictionary of the Ukrainian language] / ed. V. V. Dubichinsky. Kh.: VD «Shkola», 2008. P. 353. 
applied problem of coordination of subjects of prevention of cross-border crime. It should be noted that coordination in the fight against crime in the context of the prerogative of the prosecutor's office remains beyond the scope of our study.

Globalization and organized nature of crime at the state border require the unification and coordination of all operational and service activities of border protection agencies and the organization of comprehensive interaction with other law enforcement agencies that participate in the protection of state borders or perform other functions assigned by the state in the border areas and areas. Taking into account the experience of development and formation of law enforcement agencies of the European community, in order to qualitatively perform the tasks of the state border guard service of Ukraine, it is necessary to study the problems of coordination.

The results of the activity of law enforcement agencies, which are the subjects of law enforcement activity at the state border, to some extent depend on the well-established coordination of their actions and interaction between them.

There is a question of differentiation of these concepts. We believe that the goal of coordination is to create an appropriate regime of relations between the actors, in which the implementation of agreed tasks is achieved with the least effort, money and time. The purpose of interaction is the implementation of certain concerted actions aimed at achieving a specific result. In particular, the preparation of integrated plans, preparation of management decisions, coordination meetings belong to coordination. And the implementation of joint measures to detain the offender, carrying out complex measures to ensure border security is an interaction.

In addition, the presence or absence of subordination relationships between subjects. In contrast to interaction, in which the subjects are equal, that is, do not have authority over each other, during the coordination one of the subjects of the state border protection has the right to give binding instructions to other participants. The last criterion of differentiation is the purpose of coordination and interaction. The purpose of coordination of subjects of protection of the state border is creation of the corresponding mode of relations between these subjects at which performance of the agreed tasks by them is reached with the least expenses of forces, means and time. The purpose of interaction of subjects of protection of the state border is the implementation of certain concerted actions aimed at achieving a specific result.

Analysis of legislation that regulates the activity of bodies of executive power concerning ensuring of national security in the border area, showed that bodies of border protection solely posses the functions regarding the state border crossing by persons, vehicles and goods, maintain the established regime at the checkpoints, the illicit movement of persons across the state border, illegal migration, human trafficking, and illegal movement of weapons, drugs, psychotropic substances and precursors, ammunition, explosives, materials and 
articles prohibited for transfer across the state border. Customs and other state control bodies, ensuring economic and environmental security, under the existing legislation must ensure strict compliance with quotas for the import and export of industrial and agricultural products, the movement across the border of energy and other natural resources. Other bodies of the state control are obliged, providing ecological safety, to prevent transporting to the territory of Ukraine of diseases of epidemic character of people, animals, birds and plants. Practice shows that, while ensuring stability and evolutionary development of the country and environment, it is necessary to protect its space from external negative impact. The efforts of the control bodies at the checkpoints are aimed at achieving this goal. This task is solved in the conditions of continuously growing flow of persons and vehicles across the state border.

Coordination of activities of law enforcement, regulatory bodies and service providers is carried out on the grounds and in the manner specified in the Laws of Ukraine «On the State border guard service of Ukraine», «On border control», resolutions of the Cabinet of Ministers of Ukraine dated 18.01.1999 № 48 «On approval of Procedure of coordination of activity of bodies of executive power and bodies of local self-government on the issues of observance of regimes at the state border» dated 24.12.2003, No. 1989 «Issues of crossing the state border by persons, automobile, water, railway and air vehicles of carriers and goods transported by them», of 18.08.2010 № 751 «On approval of Provisions on checkpoints across the state border and control points», dated 22.08.2011 № 893 «On approval of Rules of sanitary protection of the territory of Ukraine».

In particular, according to the article 2 of the Law of Ukraine «On the State border guard service of Ukraine» the main functions of the State border guard service of Ukraine include coordination of the activity of military formations and law enforcement agencies related to the protection of the state border of Ukraine, and also activities of state bodies, carrying out various types of control when crossing the state border or contribute to the state border regime, the border regime and the regime at checkpoints across the state border of Ukraine. In fact, it means, among other things the coordination of bodies that are subjects of crime prevention.

According to part 5 of article 2 of the Law of Ukraine «On border control» border control is provided by coordinating the actions of control bodies and services. At the same time, according to article 1 of this Law, control bodies and services are state bodies and services that control the level of ionizing radiation, phytosanitary, veterinary and sanitary control, state control over compliance with legislation on food, feed, animal by-products, animal health and welfare. This provision cannot be considered well formulated, because it establishes that these bodies «carry out statutory inspections, which are performed in accordance with 
the legislation of Ukraine» ${ }^{11}$. Coordination at the state border, which is carried out by the border protection authorities, is a traditional practice not only for Ukraine. For example, according to article 16 of the Model Law «On border guard agencies (forces)», approved by the Resolution of the Interparliamentary Assembly of the CIS of May 17, 2012, the border guard agency in the field of border security coordinates the actions of executive authorities that perform sanitary-quarantine, veterinary, phytosanitary, automotive and other types of control at the state border, without interfering with the actions of such bodies. This model law refers to this type of coordination as «coordination of border guard activity», which is correct and reflects the essence of the phenomenon.

Let's consider the approaches to the general content of the concept of «coordination». In order to generalize scientific approaches to this term, it is possible to draw a conclusion that its contents are considered as a basis of relations between bodies of one organizational and legal level which is expressed in coordination of actions, decisions, in joint consultations, mutual discussions, conducting common actions. As a rule, these actions are performed by publication of joint acts between bodies, subjects of coordination. A similar approach is that coordination is a function that ensures coordination of the activity of management systems and coordination of actions not only of managers within the management level, but also of managers of other management structures.

M. M. Lytvyn defines coordination as a management function, the essence of which is « the establishment of horizontal links between the subjects and objects of management, that is, the implementation of a system of measures that ensure the achievement of the planned result. Coordination relations differ by types: coordination, technological interaction, hierarchical interaction ${ }^{12}$

Thus, characterizing the essence of coordination, Ukrainian scientists often focus on the interdependent, coordinated nature of the activity of various actors. It should be noted that in the context of the studied problem, the departmental normative-legal act defines coordination as a managerial function of the SBGSU, which unites and systematizes the efforts of control bodies and services to ensure the passage of persons, vehicles and goods across the state border according to the technological schemes/

Let us determine the place of the type of coordination we are analyzing in the system of integrated border management. M. M. Lytvyn distinguishes four levels of integrated border management: international, interstate, national, border

${ }^{11}$ Pro prykordonnyy kontrol': Zakon Ukrayiny Zakon Ukrayiny vid 5.11.2009 r. [On border control: the Law of Ukraine] of 5.11.2009 No. 1710-VI URL: http://zakon2.rada.gov.ua/ laws/show/1710-17/print1520522429510622

${ }^{12}$ Intehrovane upravlinnya kordonamy : pidruchnyk / za red. M. M. Lytvyna. [ntegrated Border Management: a textbook / ed. MM Litvin.] Khmel'nyts'kyy : Vyd-vo NADPSU, 2012. P. 46. 
guard. The border guard level of integrated management includes cooperation on the protection of the state border, compliance with the state border and border guard regime ${ }^{13}$. It is obvious that there are grounds to consider the coordination of activity of the state bodies and services on the organization and implementation of border control as a component of integrated management at the border guard level.

The spheres within which the central executive body implementing the state policy in the field of protection of the recreation area is coordinated, in fact, are the spheres of protective activity:

organization and implementation of the passage across the state border of persons, vehicles, cargo; compliance by all non-military vessels and warships with the established order of navigation and stay in the territorial sea, internal waters, as well as in the waters of border rivers, lakes and other bodies of water belonging to Ukraine;

carrying out various works, industrial and other activity on the state border within the border zone;

compliance with the border regime in the border zone and the controlled border area, the regime at checkpoints across the state border;

settlement of border incidents at the state border (border incident - an incident at the border that occurred as a result of illegal actions of local residents, military personnel or authorities of one or another party, including various violations of the border regime and agreements on border issues)\$ border.

involving citizens of Ukraine to participate in the protection of the state

2. Features of coordination of joint border activity

According to the order the purpose of coordination is to ensure compliance with the requirements of legislation on border issues, rational use of forces and means, avoiding duplication of measures taken to comply with law and order at the state border, as well as during the implementation of border, customs and other types of control. Based on the above, it can be concluded that coordination is designed to maintain a balance between effective activities to counter crossborder offenses and simplification of border guard formalities for law-abiding citizens. In case of martial law and state of emergency, the established coordination procedure does not apply. Classification of structural units of the state bodies, local governments, organizations that are subjects of coordination on the functional basis is given in table. 1 .

\footnotetext{
${ }^{13}$ Ibid, p. 103.
} 
Table 1

\section{Classification of coordination subjects}

\begin{tabular}{|c|c|}
\hline Group & List of coordination subjects \\
\hline $\begin{array}{l}\text { I group - } \\
\text { structural subdivisions of bodies } \\
\text { and organizations engaged in } \\
\text { various types of control of persons, } \\
\text { vehicles and goods abroad }\end{array}$ & $\begin{array}{l}\text { - customs authorities (after the separation of the } \\
\text { State Fiscal Service in 2019); } \\
- \text { veterinary and phytosanitary control bodies } \\
\text { (Minagroprom); } \\
- \text { control bodies of ionizing radiation of the } \\
\text { Ministry of Environmental Safety } \\
- \text { bodies of sanitary and quarantine control } \\
\text { (Ministry of Health); } \\
- \text { bodies of control over the movement of cultural } \\
\text { property of the Ministry of Culture; } \\
- \text { units of the inspectorate for safety on land } \\
\text { transport of the Ministry of Infrastructure (border } \\
\text { crossing points for automobile and railway } \\
\text { communications.)); } \\
- \text { the service of aviation safety (aviation service of } \\
\text { the Ministry of Infrastructure (border crossing points } \\
\text { for air traffic)); } \\
- \text { Maritime security service of the port (sea, river, } \\
\text { specialized) - Ministry of Infrastructure (checkpoints } \\
\text { for sea (river) communication)) }\end{array}$ \\
\hline $\begin{array}{l}\text { Group II - } \\
\text { Units of law enforcement agencies, } \\
\text { military formations, as well as } \\
\text { organizations entrusted with the } \\
\text { task of protecting objects, } \\
\text { protecting public order and } \\
\text { maintaining the regime at } \\
\text { checkpoints }\end{array}$ & $\begin{array}{l}\text { - structural units of the National police; } \\
\text { - structural units of air defense of the Ministry of } \\
\text { Defense of Ukraine; } \\
\text { - structural divisions of The State Migration } \\
\text { Service; } \\
\text { - paramilitary departmental and interdepartmental } \\
\text { protection; } \\
\text { - watchman service. }\end{array}$ \\
\hline $\begin{array}{l}\text { Group III - } \\
\text { Heads of local self-government } \\
\text { bodies, state bodies, enterprises, } \\
\text { institutions or organizations, on the } \\
\text { land plot of which there are } \\
\text { checkpoints (control points) }\end{array}$ & $\begin{array}{l}\text { - chiefs of sea (river) ports; } \\
\text { - chiefs of airports (airfields); } \\
\text { - chiefs of railway stations; } \\
\text { - heads of local governments. }\end{array}$ \\
\hline Group IV & $\begin{array}{l}\text { heads of the enterprises, institutions or organizations } \\
\text { that organize transportation across the state border }\end{array}$ \\
\hline
\end{tabular}

A systematic list of functions inherent in the coordination entities in the field of border guard activity is presented in table 2 . 


\section{Functions of the subjects of coordination in the field of border guard activities}

\begin{tabular}{|c|c|}
\hline $\begin{array}{c}\text { Subjects of } \\
\text { coordination }\end{array}$ & Main function \\
\hline $\begin{array}{l}\text { Custom authority } \\
\text { (after the division of } \\
\text { the SFS in 2019.) }\end{array}$ & $\begin{array}{l}-\quad \text { customs control and customs clearance of goods and vehicles; } \\
-\quad \text { the fight against smuggling and violations of customs rules; } \\
\text { - reconstruction, construction and arrangement of international } \\
\text { and interstate checkpoints across the state border for automobile } \\
\text { communication, as well as other functions }\end{array}$ \\
\hline $\begin{array}{l}\text { Ministry of } \\
\text { infrastructure }\end{array}$ & $\begin{array}{l}\text { - organization of transport communication across the state } \\
\text { border; } \\
- \text { reconstruction, construction, repair and maintenance of } \\
\text { checkpoints across the state border for rail, sea, river and air traffic; } \\
- \text { submission to the CMU of proposals for the creation of new } \\
\text { and changing the status of existing checkpoints across the state } \\
\text { border; } \\
- \text { addressing road construction issues in border areas; } \\
- \text { implementation of intergovernmental agreements on } \\
\text { international transport and control over aviation and railway } \\
\text { security, as well as other activities within the competence of the } \\
\text { Ministry of infrastructure }\end{array}$ \\
\hline $\begin{array}{l}\text { Ministry of Foreign } \\
\text { Affairs }\end{array}$ & $\begin{array}{l}\text { - coordination of the negotiation process with the adjacent states } \\
\text { and international organizations; } \\
-\quad \text { dealing with the issues of visa entry to Ukraine by foreign } \\
\text { citizens }\end{array}$ \\
\hline Ministry of defense & $\begin{array}{l}- \text { protection of the state border in the airspace by air defense } \\
\text { forces }\end{array}$ \\
\hline $\begin{array}{l}\text { Ministry of agrarian } \\
\text { policy and food }\end{array}$ & $\begin{array}{l}\text { - veterinary } 45 \text { and phytosanitary control at checkpoints across } \\
\text { the state border }\end{array}$ \\
\hline Ministry of health & $\begin{array}{l}\text { - sanitary and quarantine control, medical care of citizens at } \\
\text { checkpoints across the state border }\end{array}$ \\
\hline $\begin{array}{l}\text { Ministry of ecology } \\
\text { and natural resources }\end{array}$ & $\begin{array}{l}\text { - state control over compliance with the requirements of } \\
\text { legislation on environmental protection in the border zone, the } \\
\text { controlled border area and the exclusive (Maritime) economic zone } \\
\text { of Ukraine; } \\
- \text { environmental control at checkpoints across the state border }\end{array}$ \\
\hline National police & $\begin{array}{l}\text { - crime combating and prevention; } \\
\text { - ensuring public security and order within the border zone, } \\
\text { controlled border area }\end{array}$ \\
\hline $\begin{array}{l}\text { State migration } \\
\text { service }\end{array}$ & $\begin{array}{l}\text { - execution of the court decision on the forced expulsion of foreigners } \\
\text { and stateless persons from } \\
\text { Ukraine, as well as control over the correct and timely execution of } \\
\text { decisions on their forced return to the country of origin or a third country }\end{array}$ \\
\hline Ministry of culture & $\begin{array}{l}\text { - control at checkpoints across the state } \\
\text { border for the export from Ukraine and import into its territory of } \\
\text { cultural property }\end{array}$ \\
\hline $\begin{array}{l}\text { CM of the ARC, } \\
\text { local state } \\
\text { administrations and } \\
\text { local self-government } \\
\text { authorities }\end{array}$ & $\begin{array}{l}\text { - measures to comply with the border regime in the border zone } \\
\text { and the controlled border area; } \\
- \text { creating conditions for the operation of checkpoints across the } \\
\text { state border; } \\
- \text { general management of public organizations regarding the issues } \\
\text { of public order and state border protection }\end{array}$ \\
\hline
\end{tabular}


These tables demonstrate that despite the fact that combating crossborder crime is either not characteristic at all, or is a minor feature in the structure of activity of the majority of subjects of coordination, many of the features of the subjects border on issues of preventive activity (e.g., the activity of the Ministry of culture is directed on prevention of smuggling of cultural values).

In the course of implementation of the border control, the bodies of border protection perform orders of law enforcement agencies to detain individuals in the BCP who are prohibited from entering or leaving Ukraine. The legal basis of activities when solving this task by the agencies and subdivisions of state border protection are Laws of Ukraine «On the state border of Ukraine», «On State border guard service of Ukraine», «On border control», «On combating terrorism», «On procedure of exit from Ukraine and entry into Ukraine of citizens of Ukraine», «On legal status of foreigners and persons without citizenship», decrees of the Cabinet of Ministers of Ukraine «On approval of Rules of crossing the state border by citizens of Ukraine», «On the procedure of providing the State border guard service and the fulfilment of the instructions of law enforcement bodies concerning persons who cross the state border of Ukraine», etc.

It should be noted that the bodies of the SBGSU can be both subjects and objects of coordination. For example, according to the Concept of counterterrorism, increasing the level of coordination of counter-terrorism actors is one of the tasks in this area. It is obvious that the SBGSU bodies in this context are objects of coordination ${ }^{14}$.

In general, performing of orders of law enforcement agencies is organized and carried out by units of the state border protection at checkpoints equipped with complexes of automated technical means of information and telecommunication system $\mathrm{PK}$ «Gart- $1 / \mathrm{P} »$ in the same manner as in the control of persons who are prohibited from entering Ukraine. Depending on features of the organization of documents checking, arrangement and equipment of $\mathrm{BCP}$, the accounting of the orders of law enforcement bodies are performed in special sections of information storage in a certain form. At the same time, the records should contain a minimum set of data necessary to identify wanted persons without disclosing the direct content of the operational task. Depending on the type of the BCP and the conditions of the situation, the verification of the grounds for the right to cross the state border by vehicles and goods is carried out in the process of checking documents or is a separate technological operation.

It is important to ensure a high level of interaction between the control bodies that carry out their activity on the routes of international

${ }^{14}$ Kontseptsiya borot'by $\mathrm{z}$ teroryzmom v Ukrayini. Zatverdzhena Ukazom Prezydenta Ukrayiny vid 5 bereznya 2019 roku № 53/2019 [The concept of combating terrorism in Ukraine]. Approved by presidential decree No. 53/2019 of 5 March 2019. URL: http://www.rnbo.gov.ua/documents/493.html 
communications (through the introduction of the interdepartmental information and telecommunication system «Arkan»), as well as to equip checkpoints with technical means that allow in the shortest possible time to identify any vehicle, or the nature of their cargo for the purpose of further targeted inspection.

As it is noted by K. V. Mostova, the activities of border control units is based on the obtaining, synthesis, analysis and implementation of diverse information. It has its own structure, reveals the technology of the main operations and actions for the implementation of border control. A large amount of diverse information, the constant dynamics of the operational situation (with a change in the category of issued citizens and other conditions) means hard work on the analysis, synthesis, classification, systematization of the accumulated material and its distribution. In the conditions of the border control technology rigidly regulated by normative legal acts, the personnel independently carry out planning of sequence of actions, makes the decisions corresponding to the developing situation in the BCP. Such actions are successful provided that the special skills of the personnel of the units of border protection are firmly formed. Thus, the increasing demands of the system of ensuring national security in the border guard sphere to the nature of the activity of bodies and divisions of the state border protection defines the border control as an independent direction of the operational and service activity of the SBGS of Ukraine. As an independent direction of operational and service activity, border control should have its own hierarchy of management, built on automated, systemically integrated information flows, connected not only by technical parameters, but also distributed by qualification characteristics by types of information, which is implemented at the appropriate levels of management. The border control should have independent directions of formation of requirements, creation, introduction, operation and improvement of technical means of the border control. Autonomous areas of recruitment, training and placement of personnel, which not only take into account the necessary qualification requirements for personnel from the point of view of peacetime, but also the necessary organizational and staff structure of the application of the units of border protection in the event of emergencies, crisis situations and armed conflicts. The border control system should be built in accordance with the operational and service tasks the SBGSU is faced with as a whole and the specific tasks of the bodies of the state border protection in the relevant region, as well as on the basis of legally defined responsibilities ${ }^{15}$.

Executive authorities and local self-government bodies are responsible for drawing up interaction plans. The plans define the main general measures

${ }^{15}$ Kęsek R., Boroda M., Jóźwik Z. Addressing Security Risks at the Ukrainian Border Through Best Practices on Good Governance. 2016. Vol. 129. Amsterdam. pp. 21-27. https://doi.org/10.3233/978-1-61499-710-8-21 
aimed at the prevention, timely detection and suppression of cross-border offenses and any other violations of legislation on border guard issues. Addressing the question of determining the role of coordination in combating cross-border crime, we note that in order to ensure timely and full information on the state border protection, executive and local authorities, bodies exercising various types of control while crossing the state border or participating in ensuring the regime at checkpoints across the state border, act according to the elements of interaction, which include the exchange of information through the service control centers and areas of interaction specified in table 3 .

Table 3

\section{The essence of the interaction on regimes compliance nat}

the state border: the preventive aspect

\begin{tabular}{|c|c|}
\hline \multicolumn{2}{|r|}{ Area of cooperation } \\
\hline $\begin{array}{l}\text { Development and } \\
\text { implementation of }\end{array}$ & $\begin{array}{l}\text { joint activities to identify and disclose } \\
\text { violations of legislation on border and customs issues }\end{array}$ \\
\hline $\begin{array}{l}\text { Identification and } \\
\text { disclosure of }\end{array}$ & crimes, including in the sphere of foreign economic activity \\
\hline The search and arrest & of criminals \\
\hline Counteraction & to illegal migration \\
\hline & smuggling of goods and other items across the state border; \\
\hline Organization & of traffic safety of vehicles of international communication. \\
\hline \multicolumn{2}{|r|}{ Exchange of information } \\
\hline Intentions and attempts & $\begin{array}{l}\text { to violate the state border } \\
\text { and detention of its violators }\end{array}$ \\
\hline Signs of preparation & to violation of the state border \\
\hline $\begin{array}{l}\text { Locations of gathering } \\
\text { and routes }\end{array}$ & of illegal migrant; \\
\hline Identification of persons & $\begin{array}{l}\text { concerning which there are corresponding } \\
\text { instructions of law enforcement agencies }\end{array}$ \\
\hline $\begin{array}{l}\text { Attempts to move across } \\
\text { the border }\end{array}$ & $\begin{array}{l}\text { by wanted criminals, including those from international crimina } \\
\text { groups }\end{array}$ \\
\hline Evidence & $\begin{array}{l}\text { of the acts of sabotage, terrorist acts, provocative actions and } \\
\text { conflict situations at checkpoints across the state border, in the } \\
\text { border zone and the controlled border area }\end{array}$ \\
\hline Evidence and channels & $\begin{array}{l}\text { of illegal movement across the state border of goods and other } \\
\text { items, currency, raw materials, hazardous substances and waste, } \\
\text { cultural and historical values, stolen vehicles }\end{array}$ \\
\hline
\end{tabular}

\section{CONCLUSIONS}

Summing up, we note that the problem of optimizing the system of ensuring the protection of the state border of Ukraine requires a solution at the legislative level. In the Law of Ukraine «On the state border of Ukraine» it is necessary to clearly define the powers of public authorities engaged in the protection of the state border regime of Ukraine, the mechanism of their 
interaction and coordination. Protection of the state border of Ukraine is carried out by a fairly extensive system of public authorities. Given this, an important aspect of such a system is the coordination of the activity of its actors. The above shows that the main vector of coordination of activity of the state bodies and services on the organization and implementation of border control is aimed at maintaining a balance between effective activity to counter cross-border offenses and simplification of border formalities for law-abiding citizens.

In the field of movement of goods with the aim of introducing the concept of «smart borders» and the best European practices necessary to realize such tasks as: a) control of cross-border movement of goods through the introduction of electronic identification of goods and introduction of taxinvoice or e-invoice; b) introduction of common transit system with the neighboring countries (at least EU), which will allow the direct exchange of the databases of customs authorities of neighboring countries; analysis of import prior to arrival of goods at the customs border, which will oppose the importation of counterfeit goods as «interrupted transit»; c) integration of the customs databases of the neighboring states in the regime of «querysharing»; d) improving control of international travels of citizens.

Particular attention should be paid to the provision of authorized bodies with the authority to collect, process and store personal data; ensuring the effectiveness of software and analytical tools for processing PNR (Passenger Name Record); interoperability of databases of the SBGSU, other law enforcement agencies and Interpol; prevention of cross-border movement of terrorists and related assets, including through the use of border control units of Interpol databases, the use of API (notification by transport companies of passenger data before arrival for border control), various ways to ensure the protection of travel documents.

\section{SUMMARY}

The results of the activity of law enforcement agencies, which are the subjects of law enforcement activity at the state border, to some extent depend on the well-established coordination of their actions and interaction between them.

To resolve this problem, the following questions have been answered: what is the importance of the $\mathrm{BC}$ nowadays in the system of counteraction to criminal threats in general ? what aspects of border crossing points across the state border have the greatest impact on the effectiveness of coordination? Special emphasis is what trends will determine the effectiveness of the coordination in the context of counteracting crime. As an 
independent direction of operational and service activity, border control should have its own hierarchy of management, built on automated, systemically integrated information flows, connected not only by technical parameters, but also distributed by qualification characteristics by types of information, which is implemented at the appropriate levels of management. The aim of coordination is to optimize the joint border activity of the state border guard service and control services. Including: regulating the order of actions in case of non-standard situations; ensuring smooth functioning of border crossing points; ensuring compliance with the requirements of legislation on border issues; rational use of available forces and means. Special emphasis is avoiding duplication of control procedures, compliance with regime rules, maintaining the openness of the border for legitimate cross-border activities.

\section{REFERENCES}

1. Pro Derzhavnu prykordonnu sluzhbu Ukrayiny: Zakon Ukrayiny vid 3 kvitnya 2003 roku [On the State border service of Ukraine: Law of Ukraine] No. 661-IV of 3 April 2003. URL: http://zakon3.rada.gov.ua/laws/show/661-15/print1533466816482616.

2. Pro prykordonnyy kontrol': Zakon Ukrayiny Zakon Ukrayiny vid 5.11.2009 r. [On border control: the Law of Ukraine] of 5.11.2009 No. 1710VI URL: http://zakon2.rada.gov.ua/laws/show/1710-17/print15205224295 10622 .

3. Stratehiya intehrovanoho upravlinnya kordonamy na period do 2025 r. Skhvalena rozporyadzhennyam KMU vid 24 lypnya 2019 r. № 687-r. [Integrated border management strategy]. Approved by the order of the CMU dated July 24, 2019 No. 687-R. URL: https://www.kmu.gov.ua/ storage/app/uploads/public/5d6/904/d22/5d6904d225eb5667852251.doc

4. Mostova K. (2017) Orhanizatsiyno-pravovi zasady prykordonnoho kontrolyu $\mathrm{v}$ punktakh peretynu derzhavnoho kordonu Ukrayiny [Organizational and legal basis of border control at the state border crossing points of Ukraine]. University scientific notes. No. 62, Pp. 241-254. P. 245.

5. Stavytskyi, O. (2013) Teoriya i praktyka orhanizatsiyi ta zdiysnennya prykordonnoho kontrolyu $\mathrm{v}$ konteksti zabezpechennya natsional'noyi bezpeky Ukrayiny $\mathrm{v}$ prykordonniy sferi : monohrafiya.[Theory and practice of organization and implementation of border control in the context of national security in the border guard area: monograph]. Khmelnytskyi: NADPSU Publishing house. 360 p. 
6. Filippov S. (2019) Protydiia transkordonnii zlochynnosti: hlobalnyi kontekst i realii Ukrainy: monohrafiia [Countering cross-border crime: the global context and realities of Ukraine] Odesa: Feniks. 452 p.

7. Suchasnyy tlumachnyy slovnyk ukrayins'koyi movy [Modern explanatory dictionary of the Ukrainian language] / ed. V. V. Dubichinsky. Kh.: VD «Shkola», 2008. $832 \mathrm{p}$.

8. Intehrovane upravlinnya kordonamy : pidruchnyk / za red. M. M. Lytvyna. [ntegrated Border Management: a textbook / ed. MM Litvin.] Khmel'nyts'kyy : Vyd-vo NADPSU, 2012. P.46

9. Filippov S., Maltsev A., Voitsekhivskyi O. Osoblyvosti koordynatsiyi diyal'nosti derzhavnykh orhaniv i sluzhb z pytan' orhanizatsiyi ta zdiysnennya prykordonnoho kontrolyu. Mytna sprava/ [Features of coordination of activity of the state bodies and services concerning the organization and implementation of border control. Customs matter]. 2013. No. 1 (85). Part 2. book 2. p. 105-113 + 4 p. Attachment

10. Kontseptsiya borot'by $\mathrm{z}$ teroryzmom $\mathrm{v}$ Ukrayini. Zatverdzhena Ukazom Prezydenta Ukrayiny vid 5 bereznya 2019 roku № 53/2019 [The concept of combating terrorism in Ukraine]. Approved by presidential decree No. 53/2019 of 5 March 2019. URL: http://www.rnbo.gov.ua/documents/493.html

11. Kęsek R., Boroda M., Jóźwik Z. Addressing Security Risks at the Ukrainian Border Through Best Practices on Good Governance. 2016. Vol. 129. Amsterdam. pp. 21-27. https://doi.org/10.3233/978-1-61499-710-8-21

\section{Information about the author:} Valerii Kukhar,

$\mathrm{PhD}$ in Law, Associate Professor, Dean of the Law Enforcement Faculty Bohdan Khmelnytskyi National Academy of the State Border Guard Service of Ukraine 46 Schevchenko str., Khmelnitsky, Ukraine, 29007 ORCID ID: orcid.org/0000-0002-9627-2953 